\title{
Aggregate Fluctuations with National and International Returns to Scale
}

\author{
Allen C. Head ${ }^{1}$ \\ Department of Economics \\ Queen's University \\ Kingston, Ontario \\ Canada, K7L 3N6
}

June 2001

\begin{abstract}
Cyclical movements in aggregate output, factor inputs, and productivity are all positively correlated across countries. This paper proposes a model in which positive cross-country correlations of these variables result from increasing returns to the world-wide variety of intermediate goods even if technology shocks are purely country-specific. The model also accounts for the observed positive relationship between bilateral trade volume and international co-movements. Positive co-movements can also arise with constant returns to variety, but only if technology shocks are themselves strongly correlated. The combination of constant returns and common shocks, however, tends to generate pro-cyclical fluctuations of the trade balance.
\end{abstract}

1 Martin Boileau, Beverly Lapham, two anonymous referees and an associate editor provided helpful comments. The Social Sciences and Humanities Research Council of Canada provided financial support for this research. 


\section{Introduction}

Analysis of international data has established that aggregate output, factor inputs, and total factor productivity are all strongly correlated across countries. Standard business cycle models are typically capable of generating positive correlations of these variables only if exogenous productivity fluctuations are themselves highly correlated. This paper proposes a model which can generate high cross-country correlations of output, factor inputs, and the Solow residual even if the primitive technology shocks are uncorrelated across countries. The key feature of the model is increasing returns to the world-wide variety of intermediate goods, similar to that proposed in the static international trade model of Ethier (1982).

Evidence for positive co-movements of economic activity among developed countries has been presented by many authors. For example, Backus, Kehoe, and Kydland (1995) show that for most developed countries taken pair-wise, aggregate output, investment, employment, and productivity are all positively correlated. Gregory, Head, and Raynauld (1997) also find that among the G7 countries, common fluctuations account for up to 60 percent, 67 percent, and 46 percent of the variances of total factor productivity, output, and investment, respectively.

Many recent studies have considered the extent to which dynamic general equilibrium models can account for these co-movements. These studies (e.g. Backus, Kehoe, and Kydland $(1992,1994)$; Baxter and Crucini (1993); and Stockman and Tesar (1995)) typically assume constant returns and perfect competition and model aggregate fluctuations as principally driven by exogenous productivity shocks. These shocks drive fluctuations in output, employment and investment through the dual channels of intertemporal substitution of leisure and capital accumulation. For a given country, aggregates respond to fluctuations in productivity relative to both the long-run average level of domestic productivity and to foreign productivity. Productivity differentials tend to produce negative co-movements of output, employment, and investment, while correlated movements in the levels of productivity tend to produce positive co-movements.

Models with constant returns generally possess no mechanism for the international transmission of productivity fluctuations. As a result, in these models country-specific technology shocks produce relatively large fluctuations in productivity differentials and tend to generate negative co-movements of output, investment, and employment. Only if exogenous productivity shocks are assumed to be sufficiently positively correlated, or to "feed-back" across countries over time, are these models capable of generating positive co-movements of both output and factor inputs across countries.

In the model considered here, varieties of both domestic and foreign producer goods are used as intermediate inputs in the production of final consumption-investment goods in both countries. 
Returns to scale operate through changes in the world-wide variety of these producer goods, as considered by Ethier (1982), Markusen (1989) and others in the trade literature, and by Romer (1987) and Jones (1995) in the growth literature. As in the model studied by Jones, returns to the introduction of new varieties are substantial but insufficient to generate endogenous growth. With this type of "international return to scale" (to use Ethier's term), an increase in one country's variety of producer goods can raise total factor productivity in both countries simultaneously. If this trade-induced link between different countries' productivities is strong enough, output, employment and investment will be positively correlated across countries as well.

The empirical importance of trade in varieties of differentiated intermediate goods (a form of "intra-industry" trade) has been documented by many authors. According to one OECD (1996) study, the share of total trade that is intra-industry (measured by the Grubel-Lloyd (1975) index) exceeds 50 percent for 16 of 22 OECD countries in 1990, and for many countries it is substantially higher. For example, this same study estimates shares of intra-industry trade for the U.S., France, Germany, and the U.K. all in excess of 70 percent.

Evidence of a link between intra-industry trade and aggregate fluctuations is provided by Frankel and Rose (1998). For twenty-one industrial countries over the period 1959-93, they find that bi-lateral trade intensity is positively related to the cross-country correlation of economic activity at a point in time, and that country pairs which experience an increase in bi-lateral trade intensity also experience a strengthening of co-movements. These findings are consistent with the model studied here, but are inconsistent with many dynamic international models in which trade takes place only in final goods. For example, the cross-country correlation of output falls in the model of Backus, Kehoe, and Kydland (1992) as a barrier to international trade is weakened.

The remainder of the paper is organized as follows. Section 2 uses a simple two-country model without capital to illustrate analytically the relationships among international returns to scale and the cross-country co-movements of output, employment, and productivity. Section 3 adds capital to the model and relaxes some symmetry assumptions. Aggregate fluctuations and co-movements for a baseline calibration of this economy are considered in Section 4, and the effects of changes to selected parameters are considered in Section 5. Section 6 concludes.

\section{A Simple Economy with no Capital}

A simple two-country economy with no capital is now presented. In spite of several simplifying assumptions, this environment is sufficient to illustrate qualitatively the relationships among international co-movements of productivity, output, and employment. Analysis of co-movements 
of investment is postponed until capital is added to the model in the next section.

The world economy consists of two symmetric countries, each populated by a large number of identical households. In each country a single differentiated consumption good is produced by a competitive industry using only intermediate inputs. Also in each country a measure of differentiated producer goods is produced by a monopolistically competitive industry using only labor under conditions of free entry. In both countries the market for labor is competitive. Households own equal shares in all domestic firms and consume only domestically produced consumption goods. Trade takes place between agents in different countries in producer goods and one step ahead state-contingent claims.

Let $N_{i t}$ denote the measure country $i(i=1,2)$, producer goods at time $t$. Country $i$ producer goods are indexed by $j \in\left[0, N_{i t}\right]$. The world-wide measure of these goods is given by $N_{t} \equiv N_{1 t}+N_{2 t}$. Each variety of producer good is produced by a monopolist using an increasing returns to scale technology:

$$
M_{j t}=z_{i t} A h_{j t}-\phi, \quad A, \phi>0 \quad i=1,2, \quad j \in\left[0, N_{i t}\right],
$$

where $h_{j t}$ is the quantity of country $i$ labor employed in production of producer good $j$, and $z_{i t}$ is a country-specific technology shock affecting all country $i$ producer good firms symmetrically. Note that producer goods in different countries are produced using technologies that are entirely symmetric except for their technology shock and the nationality of the labor that they employ.

Consumption goods in each country are produced by a large number of identical competitive firms using symmetric, constant elasticity of substitution technologies, $i=1,2$

$$
f_{i t}=N_{t}^{\lambda}\left[\int_{0}^{N_{1 t}} m_{i j t}^{\rho} d j+\int_{0}^{N_{2 t}} m_{i j t}^{\rho} d j\right]^{\frac{1}{\rho}} \quad \rho \in(0,1) \quad \lambda+1 / \rho \geq 1
$$

where $m_{i j t}$ denotes the quantity of producer good $j$ employed in production of the country $i$ consumption good at time $t$. The elasticity of substitution between any two producer goods in the consumption goods technology is given by $1 /(1-\rho)$.

Technology (2.2) exhibits increasing returns to the variety of producer goods. If a country $i$ consumption good producer employs all inputs in the same quantity, $m_{i t}$, its output is $f_{i t}=$ $N_{t}^{\lambda+\frac{1}{\rho}} m_{i t}$. Thus the technology exhibits constant returns to the quantity employed of a fixed number of producer goods, but increasing returns (of degree $\lambda+1 / \rho$ ) to expansions of variety holding fixed the quantity employed of each producer good. In the spirit of Ethier (1982) returns to variety will be referred to as international returns to scale. These are distinguished from national 
returns to scale which are those occurring at the firm level due to the presence of fixed costs in the producer goods technology, (2.1). As in Ethier (1982) and Hornstein (1993) the parameter $\lambda$ controls returns to variety independently of the substitutability of producer goods.

In each country there is a unit measure of identical households. A representative household in country $i$ is endowed with one unit of time per period and has preferences ordered by:

$$
E_{0}\left[\sum_{t=0}^{\infty} \beta^{t}\left[\gamma \ln C_{i t}+(1-\gamma) \ln \left(1-H_{i t}\right)\right]\right] \quad \gamma \in(0,1),
$$

where $C_{i t}$ and $H_{i t}$ denote consumption and hours worked by the household.

Feasible allocations are characterized by the following: $\forall t, i=1,2, j \in\left[0, N_{i t}\right]$,

$$
\begin{aligned}
C_{i t} & \leq F_{i t} \\
m_{j 1 t}+m_{j 2 t} & \leq M_{j t} \\
\int_{0}^{N_{i t}} h_{j t} d_{j} & \leq H_{i t} \\
H_{i t} & \leq 1,
\end{aligned}
$$

where $F_{i t}$ denotes aggregate output of the country $i$ consumption good.

The technology parameters are assumed independent and identically distributed across countries and over timed, and have support $[\underline{z}, \bar{z}]$, where

$$
\bar{z}<\left[\frac{1+\gamma}{1-\gamma}\right] \underline{z} .
$$

Condition (2.8) ensures that output of producer goods in each country is positive in all periods.

A symmetric equilibrium is characterized in two stages. First, the static optimization problems of firms are solved conditional on the aggregate supply of labor. Then the household optimization problem is solved to determine labor supply conditional on the pricing decisions of producer goods firms and the wage.

Each period, consumption goods producers choose $f_{i t}$, and $m_{i t}$ for $i=1,2$ and $j \in\left[0, N_{i t}\right]$ to maximize profits taking the prices of consumption and producer goods, $q_{i t}$ and $p_{j t}$ respectively, as given. Each producer goods firm maximizes profits by choosing price taking the demand for its output and the wage, $w_{i t}$, as given. Attention is restricted to a symmetric equilibrium in which each producer good firm in country $i$ produces the same quantity, $M_{j t}=M_{i t}$ for all $j \in\left[0, N_{i t}\right]$, and sells for the same price, $p_{j t}=p_{i t}$. In this case each such firm employs an equal share of the aggregate labor supply for country $i$ :

$$
h_{j t}=\frac{H_{i t}}{N_{i t}} \quad j \in\left[0, N_{i t}\right], \quad i=1,2 .
$$


The profit maximization problems and their solutions are described in detail in the appendix. There it is shown that firm optimization and factor market clearing give rise to:

$$
\begin{aligned}
q_{2 t} & =q_{1 t}=q_{t} \\
N_{i t} & =z_{i t}\left[\frac{(1-\rho)}{\phi}\right] A H_{i t} \\
p_{1 t} & =p_{2 t}=p_{t}=N_{t}^{\lambda+\frac{1-\rho}{\rho}} q_{t} \\
w_{i t} & =\frac{p_{t} N_{i t} M_{j t}}{H_{i t}}
\end{aligned}
$$

Equation (2.10) says that the relative prices of the two consumption goods is 1 and follows directly from the symmetry of consumption goods technologies. The equilibrium number of varieties in each country (2.11) is determined by the free entry (zero profits) conditions. Equality of producer goods prices across countries, (2.12), also follows from zero profits and the form of the consumption goods technology, (2.2). In this economy output of each variety of producer good is a constant function of economy parameters,

$$
M_{j t}=M=\frac{\rho \phi}{1-\rho} \quad \forall t, \quad j \in\left[0, N_{t}\right] .
$$

The producer good price (2.12) then follows from the requirement that price equal unit cost in the consumption good industries. Equation (2.13) follows from competition in the labor market and zero profits in the producer goods industries.

Equations (2.10) and (2.12) imply that international relative prices are constant in the symmetric equilibrium, i.e. there are no terms of trade fluctuations. Moreover, (2.12) implies that each consumption goods producer employs the same quantity of all producer goods each period, $m_{i 1 t}=m_{i 2 t}=m_{i t}, \forall t$. Thus, in this economy, unlike those studied by Backus, Kehoe, and Kydland (1994) and Aravanitis and Mikkola (1996), the substitutability between domestic and foreign goods plays no role in international co-movements.

Equations (2.10)-(2.13) express equilibrium prices and numbers of varieties as functions of the technology shocks and aggregate labor supplies, all of which are taken as given by households. Since within a country all households are identical, in equilibrium aggregate factor supplies must equal their per capita values. Conditional on these relationships, a solution to the household dynamic optimization problem characterizes an equilibrium.

A representative household in country $i$ chooses labor supply, consumption, and quantities of a complete set of one-step ahead contingent claims. A claim purchased in the current period pays 
one unit of Country 1 consumption good in the next period, contingent on the realization of the world-wide state, $S_{t}=\left(z_{1 t}, z_{2 t}\right)$. Let $f\left(S_{t+1}, S_{t}\right)$ denote the transition probability density of the state. Let $\psi\left(S_{t+1}, S_{t}\right)$ denote the price in state $S_{t}$ of a contingent claim that pays off in state $S_{t+1}$, and $B_{i}\left(S_{t+1}\right)$ denote the profile of contingent claims purchased at time $t$ by a country $i$ household. The household optimization problem is:

$$
\max _{C_{i t}, H_{i t}, B_{i}\left(S_{t+1}\right)} E_{0}\left[\sum_{t=0}^{\infty} \beta^{t} U\left(C_{i t}, H_{i t}\right)\right]
$$

subject to: $\quad \forall t, S$

$$
q_{t} C_{i t}+\int \psi\left(S_{t+1}, S_{t}\right) B_{i}\left(S_{t+1}\right) d S_{t+1} \leq w_{i t} H_{i t}+q_{t} B_{i}\left(S_{t}\right)
$$

A solution to this problem with prices and varieties given by (2.10)-(2.13) and subject to the requirement that the contingent claims markets clear state-by-state,

$$
B_{1}\left(S_{t}\right)+B_{2}\left(S_{t}\right)=0, \quad \forall S_{t}
$$

is a symmetric equilibrium.

Attention is limited to equilibria that are "perfectly pooled" in the sense of the following proposition which is proved in the appendix.

Proposition 2.1: If the marginal utilities of consumption are equalized across countries in the initial period, ( i.e. if $U_{c 10}=U_{c 20}$ ), then they are equalized in all periods and states:

$$
U_{c 1 t}=U_{c 2 t}, \quad \forall t, S_{t}
$$

Proposition 2.1 implies only that by trading contingent claims, agents can pool all country-specific risk; not that the equilibrium allocation is Pareto efficient. Monopoly power in the producer goods industry precludes this and rules out the possibility of finding an equilibrium as a solution to a social planning problem.

The feasibility constraints (2.4)-(2.7), conditions for producer equilibrium, (2.10)-(2.14), first order conditions for consumer optimization, "perfect pooling" condition (2.17), and market clearing condition (2.16) constitute a system of equations that characterize the symmetric equilibrium.

It is possible in this case to compute the symmetric equilibrium analytically. Given (2.17) consumption is equal across households, $C_{1 t}=C_{2 t}$, in all periods. Conditional on the levels of employment, $H_{1 t}$ and $H_{2 t}$ in equilibrium, (2.10)-(2.14) can be used to recover prices, the numbers of 
varieties, and the consumption level in equilibrium. The equilibrium employment levels themselves are given by:

$$
H_{i t}=\frac{1}{2}\left[1+\gamma+(\gamma-1) \frac{z_{\ell t}}{z_{i t}}\right] \quad i=1,2 \quad \ell \neq i .
$$

From (2.18) it can be seen that employment fluctuations depend only on the productivity differential between the two countries. Since $\gamma-1<0$, an increase in productivity of country $\ell$ relative to that of country $i$ results in a decrease in employment in country $i$. Country $i$ agents substitute leisure today, when they are unproductive relative to country $\ell$ agents, for leisure in the future, when they expect the pattern to be reversed. Because the productivity differential alone determines employment in the two countries, uncorrelated technology shocks unambiguously cause employment to be negatively correlated across countries.

With zero profits in equilibrium, the gross domestic product of country $i$, is equal to country $i$ labor income. Using (2.12) and (2.13) and evaluating at the base period (i.e. steady-state) price of the consumption-investment good, in equilibrium gross domestic product is given by

$$
Y_{i t}=N_{t}^{\lambda+\frac{1-\rho}{\rho}} N_{i t} M
$$

Taking logarithms and using (2.11), (2.19) becomes

$$
\ln Y_{i t}=\left[\lambda+\frac{1-\rho}{\rho}\right] \ln \left[z_{1 t} H_{1 t}+z_{2 t} H_{2 t}\right]+\ln z_{i t}+\ln H_{i t}+\Delta .
$$

where is $\Delta$ is a constant which is the same for both countries.

Consider first the case of constant international returns to scale, $\lambda+1 / \rho=1$. In this case, the first term in (2.20) vanishes and the cross country-correlation of output (in logarithms) is negative as it is driven by the negative correlation of employment. As the degree of international returns to scale rises, however, the first term in (2.20) becomes increasingly dominant. Fixing $\rho$, for a sufficiently high $\lambda$ (i.e. for a sufficiently high degree of international returns to scale), the correlation between two countries' outputs will be positive, regardless of the correlation of technology shocks across countries.

Since labor is the only factor of production, total factor productivity (the "Solow residual"), $S R_{i}$, can be written:

$$
S R_{i t}=\ln Y_{i t}-\ln H_{i t}
$$

With constant international returns the Solow residual collapses to $S R_{i t}=\ln z_{i t}+\Delta$ and exhibits the same cross-country correlation as the technology shocks. As the degree of international returns to 
scale increases, the correlation of productivity across countries increases along with the correlation of aggregate output. The negative correlation of employment across countries, however, ensures that the correlation of productivity is always less than that of output.

In summary, for sufficiently high degrees of international returns to scale the economy exhibits positive cross-country correlations of both output and productivity regardless of the correlation of technology shocks. Returns to specialization, however, cannot generate positive correlation of employment across countries in the absence of correlated technology shocks.

\section{An Expanded Artificial Economy with Capital}

The simple economy of the previous section is now modified to include capital. Preferences are also changed and certain symmetry assumptions are relaxed to allow a calibration similar to those studied elsewhere in the literature.

As before, let $N_{i t}$ denote the measure of producer goods produced in country $i=1,2$ at time $t$. The producer goods technologies are modified to include capital:

$$
M_{j t}=z_{i t}\left[k_{j t}^{\theta} h_{j t}^{1-\theta}\right]-\phi, \quad \theta \in(0,1) \quad \phi>0,
$$

where $k_{j t}$ denotes the quantity of country $i$ capital employed in production of producer good $j$, and $\theta$ is a parameter.

The consumption goods technologies are also modified, in this case to allow domestic producer goods to be relatively more useful in production of the domestic consumption good:

$$
f_{i t}=\left[N_{i t}+\alpha N_{\ell t}\right]^{\lambda}\left[\int_{0}^{N_{i t}} m_{i j t}^{\rho} d j+\alpha \int_{0}^{N_{\ell t}} m_{i \ell t}^{\rho} d \ell\right]^{\frac{1}{\rho}} \quad \rho, \theta, \alpha \in(0,1), \quad \lambda+1 / \rho \geq 1,
$$

where $\ell \neq i$. Here the parameter $\alpha$ governs the relative contribution of foreign and domestic producer goods to the production of the consumption good.

As before, technology (3.2) exhibits a form of international returns to scale. If a country $i$ consumption good producer employs all inputs in the same quantity, $m_{i t}$, its output is given by

$$
f_{i t}=\left[N_{i t}+\alpha N_{\ell t}\right]^{\lambda+\frac{1}{\rho}} m_{i t} .
$$

The degree of international returns to scale is again $\lambda+1 / \rho$ and the elasticity of substitution between producer goods is equal to $1 /(1-\rho)$.

Capital is produced from the domestic consumption good in each country using the following intertemporal technology:

$$
K_{i t+1}=(1-\delta) K_{i t}+\left[\frac{X_{i t}}{K_{i t}}\right]^{\xi} K_{i t}, \quad \delta, \xi \in(0,1]
$$


where $K_{i t}$ and $X_{i t}$ are the aggregate capital stock and investment expenditures in country $i$ at time $t$ respectively. The depreciation rate is $\delta$. If $\xi<1$ the accumulation of capital exhibits adjustment costs of the type considered by Baxter and Crucini (1993) and others.

Preferences are modified so that they are non-separable in consumption and leisure and to allow the intertemporal elasticity of substitution to be different from one:

$$
\mathrm{E}_{0}\left[\sum_{t=0}^{\infty} \beta^{t}\left[\frac{1}{1-\sigma}\left[C_{i t}^{\tau}\left(1-H_{i t}\right)^{1-\tau}\right]^{1-\sigma}\right]\right] \quad \tau \in(0,1) \quad \sigma>0 .
$$

In addition to one unit of time per household per period, each country is initially endowed with $K_{i 0}$ units of physical capital, equal shares of which are held by each household. Feasibility constraints $(2.5),(2.6)$, and (2.7) are again required, (2.4) is replaced by

$$
C_{i t}+X_{i t} \leq F_{i t}
$$

and the addition of capital requires

$$
\int_{0}^{N_{i t}} k_{j t} d j \leq K_{i t}
$$

Technology shocks are assumed to follow covariance stationary first-order autoregressive processes in logarithms,

$$
\ln z_{i t+1}=\omega \ln z_{i t}+\epsilon_{i t+1} \quad \omega \in(0,1)
$$

where $\epsilon_{1 t}$ and $\epsilon_{2 t}$ are mean zero, iid innovations with covariance matrix $\Sigma$.

A symmetric equilibrium of this economy is characterized in essentially the same way as in the previous section. To avoid repetition, the exposition here will describe only the differences.

First, with the addition of capital, symmetry requires

$$
k_{j t}=\frac{K_{i t}}{N_{i t}} .
$$

Optimization by the producer goods firms together with free entry and zero profits, leads to the following analog of (2.11)

$$
N_{i t}=z_{i t}\left[\frac{1-\rho}{\phi}\right] K_{i t}^{\theta} H_{i t}^{1-\theta}
$$

As before, all producer goods are produced in equal quantity (i.e. (2.14) continues to hold). Cost minimization by consumption goods producers requires

$$
\frac{p_{1 t}}{p_{2 t}}=\alpha\left[\frac{m_{i 2 t}}{m_{i 1 t}}\right]^{\rho-1} .
$$


With $\alpha=1,(3.11)$ and (2.14) imply equality of the prices of all producer goods regardless of their country of production. With $\alpha \neq 1$, however, goods produced in different countries will not typically have the same price. While a country $i$ consumption goods producer will employ all country $i$ varieties in the same quantity, $m_{i i t}$, and all country $\ell \neq i$ varieties in the same quantity, $m_{i \ell t}$, these two quantities will not be equalized in all periods. Similarly, since with $\alpha \neq 1$ consumption goods are no longer produced with identical technologies, their relative price will no longer be equal to one in equilibrium.

The household optimization problem remains similar to that for the simpler economy with the only significant change being that households now choose investment as well as consumption, labor supply, and one-step-ahead contingent claims. The aggregate state is now given by $S_{t}=$ $\left(K_{1 t}, K_{2 t}, z_{1 t}, z_{2 t}\right)$ and the household's dynamic problem is written

$$
\max _{C_{i t}, H_{i t}, X_{i t}, K_{i t+1}, B_{i}\left(S_{t+1}\right)} E_{0}\left[\sum_{t=0}^{\infty} \beta^{t} U\left(C_{i t}, H_{i t}\right)\right]
$$

subject to: $\quad \forall t, S$

$$
\begin{gathered}
q_{i t}\left(C_{i t}+X_{i t}\right)+\int \psi\left(S_{t+1}, S_{t}\right) B_{i}\left(S_{t+1}\right) d S_{t+1} \leq w_{i t} H_{i t}+r_{i t} K_{i t}+q_{1 t} B_{i}\left(S_{t}\right) \\
K_{i, t+1}=(1-\delta) K_{i t}+\left[\frac{X_{i t}}{K_{i t}}\right]^{\xi} K_{i t},
\end{gathered}
$$

where $r_{i t}$ denotes the rental rate of country $i$ capital.

A symmetric equilibrium is defined as in the previous section. Attention is again restricted to equilibria which are perfectly pooled in the sense defined earlier. In this case we have

$$
\frac{U_{c 1 t}}{q_{1 t}}=\frac{U_{c 2 t}}{q_{2 t}}
$$

which becomes (2.17) under the symmetry assumptions that give rise to (2.10).

As for the simpler economy, the feasibility constraints, first order conditions for firm and consumer optimization, "perfect pooling" condition, (3.14), and market clearing conditions constitute a system of equations that characterize the economy's dynamic equilibrium. In this case, it is not possible to characterize the equilibrium analytically. Imposing (3.14) for $t=0$ as an initial condition pins down an initial distribution of wealth across countries. For such a distribution it is possible to derive analytically a deterministic steady-state. The equilibrium dynamic system (see appendix) is linearized in a neighborhood of this steady-state and solved using the method of 
Blanchard and Kahn (1980). Because there are increasing returns, there is no guarantee that the equilibrium dynamics will be uniquely determined. Computational experiments indicate, however, that for the range of parameters normally considered in international real business cycle studies, the model does exhibit the saddle-path property and the local dynamics are unique.

\section{Fluctuations and International Co-movements in a Baseline Calibration}

In this section a baseline calibration of the artificial economy described in the previous section is analyzed. The effects of changing certain key parameters are considered in the next section. Table 1 contains the baseline calibration:

Table 1: Baseline Calibration Parameters

\begin{tabular}{|c|c|c|c|}
\hline Preferences & Production & Investment & Shocks \\
\hline $\begin{array}{l}\text { Discount Factor } \\
\beta=.99\end{array}$ & $\begin{array}{l}\text { Foreign Input Share } \\
\alpha=.751\end{array}$ & $\begin{array}{l}\text { Adjustment Cost } \\
\xi=.94\end{array}$ & $\begin{array}{l}\text { Persistence } \\
\omega=.9\end{array}$ \\
\hline $\begin{array}{l}\text { Intertemporal Elasticity } \\
\sigma=2\end{array}$ & $\begin{array}{l}\text { Input Elasticity } \\
\rho=.835\end{array}$ & $\begin{array}{l}\text { Depreciation } \\
\delta=.025\end{array}$ & $\begin{array}{l}\text { Standard Dev. } \\
\sigma_{\epsilon}=.0046\end{array}$ \\
\hline \multirow[t]{3}{*}{$\begin{array}{l}\text { Consumption Share } \\
\tau=.34\end{array}$} & $\begin{array}{l}\text { International Returns } \\
\lambda \in[-.19, .5833]\end{array}$ & & $\begin{array}{l}\text { Covariance } \\
\sigma_{\epsilon_{1}, \epsilon_{2}}=0\end{array}$ \\
\hline & $\begin{array}{l}\text { Capital Share } \\
\theta=.36\end{array}$ & & \\
\hline & $\begin{array}{l}\text { Fixed Cost } \\
\phi=1\end{array}$ & & \\
\hline
\end{tabular}

The economy has several parameters in common with the model studied in Backus, Kehoe, and Kydland $(1994,1995)$. The discount factor, $\beta$; elasticity of intertemporal substitution parameter, $\sigma$; consumption share, $\tau$; capital share, $\theta$; and depreciation rate, $\delta$ are all set equal to the values used in those papers. Similarly, the parameter governing the relative contribution of domestic and foreign producer goods to consumption goods production is set to be consistent with a steady-state trade share of $15 \%$. The capital adjustment cost parameter, $\xi$, is set so that the standard deviation of investment is roughly 3.3 times as large as that of output, a figure consistent with statistics for the U.S. economy over the period 1970-1990 presented in Backus, Kehoe, and Kydland (1995).

The parameter $\rho$ determines the elasticity of substitution between any two producer goods. Given the constant mark-up pricing rule, it also determines the mark-up of price over marginal cost. In the baseline calibration, this parameter is set to the inverse of the average mark-up in U.S. manufacturing estimated by Morrison (1990), and is roughly consistent with estimates by Chirinko and Fazzari (1994) and Basu and Fernald (1997). The effects of changes in this parameter on international co-movements are taken up in the next section. 
For a fixed $\rho$, the degree of international returns to scale is determined by $\lambda$. While several authors have posited increasing returns to variety of either consumption or producer goods in the trade and growth literatures they typically have not provided measures of the returns to variety. Cyclical product variety per se, however, has only very minor implications for aggregate fluctuations and international co-movements in the model considered here. Rather, as shown by Devereux, Head, and Lapham (1996) and Benassy (1996), the fact that these models posit increasing returns to variety is largely irrelevant. What is important is that they posit increasing returns that are external to the optimization problems of the consumption goods producers.

Several authors have provided evidence for the existence of external increasing returns, with the estimated degrees of increasing returns ranging widely and being considered econometrically imprecise. For example, Caballero and Lyons $(1990,1992)$ estimate external increasing returns ranging from 1.1 for the U.K. to 1.6 for France. Basu and Fernald (1997) report estimates of increasing returns for the U.S. economy of around 1.2. None of these studies, however, measure exactly the type of increasing return modeled here. Moreover, as shown by Cole and Ohanian (1999) fundamental difficulties in the measurement of shocks are likely to render obtaining better estimates extremely difficult.

In order to illustrate the effects of international increasing returns on the cross-country transmission of technology shocks, values of $\lambda$ are considered which generate international returns to scale ranging from constant returns to a degree of 2.4. This is the highest degree of international returns for which dynamics are unique in a neighborhood of the deterministic steady-state. The maximum degree of increasing returns here is, however, low relative to those sometimes assumed in the endogenous growth literature. For example, endogenous growth of the type studied by Romer (1987) will occur in this economy only if the degree of international returns to scale is equal to the inverse of the capital share, 2.78 in this case. To save space, however, detailed results will be presented only for an economy in which the degree of international returns to scale of 1.9. This level is chosen because given the other parameters in the baseline calibration it is the one that replicates the contemporaneous correlation of the Solow residual for the U.S. and an aggregation of European economies presented by Backus, Kehoe, and Kydland (1995).

"National" returns to scale in the economy studied here emanate from fixed costs in the production of producer goods. As in Devereux, Head, and Lapham (1996) and Benassy (1996) the level of fixed costs has no effect on dynamics. The parameter $\phi$ is therefore set to one arbitrarily.

The first-order autocorrelation of the technology shocks, $\omega$, is set to be consistent with a first-order autocorrelation of the Hodrick-Prescott filtered Solow residual of .7. This matches 
the autocorrelation of the U.S. Solow residuals produced by Zimmermann (1994). Innovations to the technology shock processes are assumed to be uncorrelated across countries so that any co-movement in total factor productivity in equilibrium must be due to propagation within the model. The standard deviation of the innovations to productivity, $\sigma_{\epsilon}$ is set so that with international returns of degree 1.9 the baseline economy replicates the standard deviation of the U.S. Solow residual in Backus, Kehoe, and Kydland (1995). Changes in $\sigma_{\epsilon}$ scale up or down the volatilities of all variables in equilibrium, but have no effect on relative volatilities or on co-movements.

Table 2 contains selected sample moments for six different artificial economies together with the corresponding moments for the U.S. economy taken from Backus, Kehoe, and Kydland (1995). The second and third sets of moments in Table 2 are sample moments for a baseline calibration economy with a degree of international returns to scale of 1.9 and an economy which differs from the baseline calibration only in that there are constant international returns. The last four sets of moments are for economies with parameters different from those in the baseline calibration and are discussed in the next section.

In each computational experiment, the deterministic steady-state of the artificial economy is imposed as the initial condition and 1000 realizations of the equilibrium stochastic process, each 626 periods in length, are computed. For each realization the first 500 periods of artificial data are discarded, and the remaining observations (in logarithms) are filtered with the Hodrick-Prescott filter. The reported sample moments are means and standard deviations over the 1000 repetitions. Attention is restricted to fluctuations of and international co-movements among consumption, $C$, gross domestic product (output), $Y$, gross capital formation (investment), $X$, employment, $H$, and total factor productivity (the Solow residual), $S R$. The correlation between the ratio of net exports to output, $N X / Y$, and output, and fluctuations in the terms of trade, TOT, are also considered.

As in the simple model of the previous section, aggregate output is equal to the value of factor payments at the steady-state prices of consumption-investment goods. The Solow residual is:

$$
S R_{i t}=\ln Y_{i t}-\theta \ln K_{i t}-(1-\theta) \ln H_{i t} \quad i=1,2,
$$

where $\theta$ determines the factor income shares due to the fact that there are zero profits in the producer goods industries. The terms of trade (TOT) is the ratio of the producer goods prices.

Consider first a comparison of the baseline economy with one in which international returns are constant. In Table 2 it can be seen that with increasing international returns to scale the contemporaneous correlations across countries of output, consumption, investment, employment, the capital stock, and productivity are all positive, whereas with constant returns all of these 
correlations except for that of consumption are negative. In Figure 1 it can be seen that the contemporaneous correlations of all of these variables increase with the degree of international returns to scale. As international returns increase, first the Solow residual, then output, investment, and employment, in that order, become positively correlated.

Intuition for the relationship between international returns to scale and international comovements is aided by considering the effects over time of a single country-specific technology shock. Figure 2 contains the responses of output, total factor productivity, investment, and employment in each country to a persistent shock to the country 1 technology parameter, $z_{1}$, for cases of both constant and increasing international returns to scale. In these experiments, the economy is initially in the deterministic steady-state and experiences a shock to Country 1 productivity that raises $z_{1}$ by one standard deviation. No subsequent shocks occur and $z_{1}$ returns to its steady-state level via process (3.8) with $\omega=.9$. The two panels on the left depict the case of constant returns. The upper and lower of these contain the responses of Country 1 and 2 aggregates respectively. The panels on the right depict the case of a degree of international returns to scale of 1.9.

Consider first the case of constant international returns to scale. Here the effects of a countryspecific technology shock are similar to what they would be in an economy with constant returns and perfect competition. The shock causes aggregate output, employment, investment, and total factor productivity in the two countries to move in opposite directions. The negative co-movement is largest for investment, followed by output, employment, and total factor productivity.

The response of total factor productivity in country 2 to a productivity shock in country 1 is, however, different from what would occur in a model with constant returns and perfect competition. In such a model with a technology of the form of (3.1), the technology shock is the Solow residual. In this economy, however, the exact correspondence between a country's Solow residual and its technology shock does not hold because of the asymmetry between the contribution of domestic and foreign varieties of producer goods to consumption goods output. Here a country-specfic technology shock raises the variety of domestic producer goods and reduces that of foreign producer goods. Because foreign inputs have a lesser impact on production than domestic ones (i.e. because $\alpha<1$ ) the combined increase in $N_{1 t}$ and reduction in $N_{2 t}$ actually lowers productivity in Country 2. The negative response of country 2 productivity disappears if $\alpha=1$ and was not present in the simple economy analyzed in section 2 .

Opposite movements in the two countries' outputs in response to the technology shock are the combined result of two effects. The first is associated with intertemporal substitution of leisure and it in turn has two components. First, agents substitute leisure intertemporally on the basis of 
the differential in productivity across countries, just as indicated by (2.18) in the analysis of the simpler economy. Second, absolute changes in productivity induce intertemporal substitution in each country, regardless of productivity in the foreign country. The latter effect was absent in the simpler model of section 2 due to the combined assumptions of logarithmic utility and no capital.

In the case of constant international returns, these effects work in the same direction for both countries and cannot be distinguished. Productivity is high for country 1 both absolutely and relative to country 2. Similarly, country 2 productivity is low relative to the steady-state. Country 1 agents forgo leisure today in exchange for leisure that they will consume in future periods when they are less productive relative to either country 2 or their own steady-state. Country 2 agents do the opposite and the shock causes employment to rise in country 1 and fall in country 2 .

The second effect of the productivity shock is to attract investment to country 1 and away from country 2, leading over time to an increase in the capital stock of country 1 and a reduction in that of country 2. Movements in the capital stock reinforce the effects of movements in employment on aggregate output.

Now consider the case of international returns to scale. In this case, the technology shock causes an increase in the variety of country 1 producer goods sufficient to raise productivity in both countries. Overall, the dynamic responses of country 1 aggregates are qualitatively similar to what they were with constant returns. Agents give up leisure today in exchange for future leisure because productivity is increased both absolutely and relative to country 2. Also, a persistent productivity differential attracts higher investment in country 1 capital. The responses of all aggregates are magnified because a given technology shock now has a stronger effect on productivity.

For country 2 , in contrast, international returns to scale change the nature of the responses of several aggregate variables. Country 2 agents continue to substitute into current leisure because of the productivity differential. They now also, however, experience an absolute increase in domestic productivity which tends to increase employment. In this case, the latter effect dominates and country 2 employment rises. This is reflected in Table 2, where employment is seen to be positively correlated across countries with increasing international returns to scale.

Country 2 investment in the case of increasing returns rises intially and then declines to its steady-state level. This dynamic response is the combined result of two factors. First, higher productivity in country 2 attracts additional investment. Second, agents in both countries increase their investment rates as they smooth consumption of their temporarily high income, and the convex adjustment costs implied by (3.4) make it costly to invest in country 1 alone. Some of the increased savings therefore flow into country 2 capital. The combination of these two effects is also 
evident in Table 2, where investment is positively correlated across countries in this case.

Overall, these experiments illustrate that sufficiently strong international returns to scale can generate co-movements in productivity, output, employment, and investment even if technology shocks are purely country-specific. With contant returns, uncorrelated technology shocks produce negative correlations of these variables as they result in productivity differentials that cause both investment and leisure to flow in opposite directions. With international returns to scale, however, a country-specific technology shock raises productivity in both countries, generates a relatively small productivity differential, and may induce positive co-movements.

While the model can generate strong co-movements across countries, it cannot (at least for the range of parameters considered here) generate output correlations which exceed the correlations of either consumption or productivity. Returning to Figure 1, the ranking and relative sizes of the correlations of different aggregates are not much affected by the degree of international returns.

Consider now the implications of international returns to scale for aggregate volatility. From Table 2 it is clear that the sample standard deviations of productivity, output, consumption, investment, employment, and the terms of trade, are all increasing in the degree of international returns to scale. With increasing returns, productivity fluctuates not only because of changes in the technology parameters, $z$, themselves, but also due to fluctuations in the world-wide variety of producer goods. As in the closed economy model of Devereux, Head, and Lapham (1996), the variances of productivity and other aggregates generated by technology shocks of a given variance is increasing in the degree of international returns to scale. Another way to look at this is that a given amount of aggregate volatility can be accounted for by smaller technology shocks as the degree of international returns rises.

Finally, output and the ratio of net exports to output are correlated negatively with increasing international returns, but positively with constant returns. Country-specific productivity shocks simultaneously raise domestic income inducing consumption smoothing by exporting (lending) to the rest of the world and raise expected future domestic productivity, attracting foreign investment through increased imports. With constant returns the former channel dominates, while with increasing returns of the magnitude considered here the latter channel does.

\section{Deviations from the Baseline Calibration}

The effects of changing certain parameters from their baseline calibration values are now considered. Only the effects of parameters which dramatically affect the relationship between international returns to scale and international comovements are described in detail. These are $\rho$, which 
governs the elasticity of substitution between varieties of producer goods; $\alpha$, which determines the steady-state trade share; $\xi$, which governs capital adjustment costs; and the covariance of technology shocks across countries, $\sigma_{\epsilon_{1}, \epsilon_{2}}$. The other parameters listed in Table 1 have little effect on the relationship between the degree of international returns to scale and the properties of aggregate fluctuations discussed here.

The fourth set of moments of Table 2 illustrates the effect of raising the elasticity of substitution between individual producer goods in the production technology of either consumption-investment good. In this experiment, $\lambda$ is adjusted so that the degree of international returns to scale remains constant at 1.9 and $\alpha$ is adjusted so that the steady-state trade share remains $15 \%$. The moments in the table show that with a higher elasticity of substitution between producer goods, aggregates are less volatile and international co-movements are stronger. From (3.10) it can be seen that the higher $\rho$, the smaller the response of domestic variety to a given technology shock. This results in a smaller response of world-wide variety, smaller productivity movements and less aggregate volatility overall. It also results in a smaller productivity differential, weakening the channel for negative co-movements. With a low elasticity of substitution between producer goods (not depicted in Table 2) these effects are reversed. Aggregates are more volatile, productivity differentials are larger, the counter-cyclical nature of the trade balance is enhanced and international co-movements are weaker.

In the experiment described above, the parameter $\alpha$ was adjusted to maintain a constant steady-state trade share. International co-movements are sensitive to changes in this parameter. For a fixed $\rho$, the trade share is directly related to $\alpha$. As can be seen from the fifth set of moments in Table 2, a reduction in the trade share lowers the impact on domestic production of an increased variety of foreign intermediates and weakens international co-movements. An increase in the trade share can be shown to have opposite effects. The relationship between $\alpha$ and international comovments is consistent with the finding of Frankel and Rose (1998) that international co-movements are positively related to bi-lateral trade intensity.

Next, consider the effects of varying adjustment costs. The most striking effect of changing the parameter $\xi$ is the inverse relationship between adjustment costs and the volatility of investment. Adjustment costs also have significant effects on the co-movements of investment and employment. With low adjustment costs a domestic productivity shock attracts relatively large amounts of foreign capital, increasing and reducing domestic and foreign investment, respectively. This reduces the cross-country correlation of investment. Low adjustment costs also, however, tend to increase the co-movements of output, employment, and productivity by strengthening the response of world- 
wide variety to a technology shock. Relatively large international capital flows with low adjustment costs contribute also to countercyclical movements in the ratio of net exports to output.

With large adjustment costs, these effects are reversed. International capital flows in response to productivity differentials are reduced. Investment fluctuations in this case are dominated by saving for the purposes of consumption smoothing and the ratio of net exports to output tends to move procyclically. At the same time, the volatility of the world-wide variety of producer goods is dampened, weakening the co-movements of employment and output.

Lastly, consider the effects of positive cross-country correlation of technology shocks. The correlation of total factor productivity may be seen as the starting point for co-movements of all the other variables. With international returns to scale, country-specific technology shocks drive the world-wide variety of producer goods and hence total factor productivity in both countries. An alternative mechanism for generating correlated movements in total factor productivity is correlated technology shocks.

The last set of moments in Table 2 contains the moments for an artifical economy with constant international returns to scale and the baseline calibration parameters except with regard to the covariance of technology shocks. The innovations to the productivity processes have a correlation of .7. This number is chosen so that the cross-country correlation of Solow residuals is the same as in the baseline calibration, where shocks are uncorrelated.

Comparing the moments for the Correlated Shocks economy with the Baseline Calibration economy, many similarities are evident. Not only are the time series properties of the Solow residuals virtually identical in the two cases, but also the correlations of output, consumption, investment, and employment are very similar. Generally speaking, only the cross-country correlation of investment differs significantly across these two cases, being higher when the source of correlated productivity movements is common shocks rather than international returns to scale.

With regard to certain other aspects of aggregate fluctuations, however, correlated shocks and international returns to scale have substantially different effects. First, with the exception of consumption, all aggregates are less volatile in the Correlated Shocks economy than in either the baseline calibration or the Constant Int'l Returns economy. The volatilities of output, investment, and employment decrease along with the volatility of productivity differentials as the correlation of technology shocks rises. Thus to account for the volatility of these aggregates, exogenous technology shocks must have greater variance in a model with common shocks only than in a model with international returns to scale. Consumption volatility, in contrast, increases with the correlation of the shocks as consumption risk becomes less internationally diversifiable. 
The dampening of fluctuations in the productivity differential in the case of common shocks is also responsible for the relatively large cross-country correlation of investment and the procyclical nature of the ratio of net exports to output. Smaller fluctuations in the productivity differential increase the importance of consumption smoothing in response to absolute productivity movements, which are positively correlated across countries. The effect is similar to that of having high capital adjustment costs, the trade balance becomes procyclical and the investment correlation rises as domestic investment absorbs a relatively large share of domestic saving in each country.

\section{Conclusions}

This paper has presented an economy which can account for positive cross-country correlations of total factor productivity, output, employment in response to purely country-specfic techology shocks. Through the mechanism of increasing returns to the world-wide variety of producer goods, these shocks induce positive contemporaneous correlations of productivity which in turn generate positive co-movements of other aggregates. In this sense, international returns to scale work much like common or highly correlated technology shocks. A model with international returns to scale, however, generates more aggregate volatility and is more consistent with the observation of countercyclical trade balances than is a model with co-movements induced by common shocks. The model is also consistent with the findings of Frankel and Rose (1998) with regard to the positive relationship between the bi-lateral trade intensity and co-movements of aggregates.

The results would change little if increasing returns operated through an explicit externality to world-wide output, perhaps akin to that studied in Baxter and King (1991), rather than through variety, per se. Formulated as it is, the model illustrates that the assumptions underlying Ethier's (1982) static trade model and Jones's (1995) model of economic growth can have important implications for aggregate fluctuations. The model is, however, unable to account for the observation that Solow residuals are often more highly correlated across countries than output and consumption. This shortcoming may be due to the fact that a very simple representation of the model has been used. Modifications aimed at making the quantitative predictions more realistic which would necessarily complicate the model have been left for future research. 


\section{Appendix}

\section{Firm Optimization}

Consumption goods producers in country $i$ choose $f_{i t}$ to solve the following static problem,

$$
\max _{f_{i}} q_{i t} f_{i t}-C^{f}\left(p_{j t} ; f_{i t}\right) \quad j \in\left[0, N_{t}\right]
$$

The cost function has the familiar form,

$$
C^{f}=\frac{f_{i t}}{N_{t}^{\lambda}}\left[\int_{0}^{N_{t}} p_{j t^{\frac{\rho}{\rho-1}}} d j\right]^{\frac{\rho-1}{\rho}},
$$

and the conditional input demand for producer good $j$ by a country $i$ consumption good producer is given by

$$
m_{i j t}=\frac{f_{i t}}{N_{t}^{\lambda}}\left[\frac{p_{j t^{\frac{1}{\rho-1}}}}{\left[\int_{0}^{N_{t}} p_{\ell t^{\frac{\rho}{\rho-1}}} d \ell\right]^{\frac{1}{\rho}}}\right]
$$

World-wide demand for producer good $j$ is given by $M_{j t}=M_{1 j t}+M_{2 j t}$.

Taking the demand (A.3) for its product as given, producer good firm $j$ chooses $p_{j t}$ to solve:

$$
\max _{p_{j t}} p_{j t} M_{j t}-C^{m}\left(w_{i t} ; M_{j t}\right)
$$

where its cost function is given by

$$
C^{m}\left(w_{i} ; M_{j}\right)=w_{i t}\left[\frac{M_{j t}+\phi}{z_{i t} A}\right] .
$$

The following conditions that must hold for each country $i=1,2$ each period in equilibrium are then derived from the conditions for optimization by firms and factor market clearing:

$$
\begin{aligned}
q_{i t} & =N_{t}^{-\lambda}\left[\int_{0}^{N_{t}} p_{j t^{\frac{\rho}{\rho-1}}} d j\right]^{\frac{1}{\rho}} \\
p_{i t} & =\frac{1}{\rho} \frac{w_{i t}}{z_{i t} A} \\
p_{i t} M_{i t} & =w_{i t}\left[\frac{M_{i t}+\phi}{z_{i t} A}\right] \\
\frac{H_{i t}}{N_{i t}} & =\frac{M_{i t}+\phi}{z_{i t} A} \\
{\left[\frac{p_{1 t}}{p_{2 t}}\right]^{\frac{1}{\rho-1}} } & =\frac{m_{1 t}}{m_{2 t}}
\end{aligned}
$$


Equation (A.6) is the requirement that consumption goods prices equal unit costs. (A.7) is the constant mark-up pricing rule that is optimal for producer goods firms. (A.8) is the zero profit condition for the producer goods industries, which results from free entry of firms in these sectors. The market clearing condition for labor in each country is (A.9). Finally, (A.10) is implied by market clearing for producer goods. Choosing consumption good 1 as numeraire, equations (A.6)(A.10) can then be solved for the equilibrium price functions and numbers of varieties given by $(2.10)-(2.13)$.

When the parameter $\alpha$ is introduced in section 3, the conditional demands (A.3) become

$$
m_{i j t}=\frac{f_{i t}}{\left[N_{i t}+\alpha N_{\ell t}\right]^{\lambda}}\left[\frac{p_{j t^{\frac{1}{\rho-1}}}}{\left[\int_{0}^{N_{i t}} p_{j t^{\frac{\rho}{\rho-1}}} d j+\alpha \int_{0}^{N_{\ell t}} p_{j t^{\frac{\rho}{\rho-1}}} d j\right]^{\frac{1}{\rho}}}\right] \quad \ell \neq i,
$$

the cost function is modified accordingly, and (A.10) is replaced by (3.11).

The addition of capital changes the cost function for producer goods firms (A.5) to:

$$
C^{m}\left(w_{i}, r_{i} ; M_{j}\right)=A r_{i t}^{\theta} w_{i t}^{1-\theta}\left[\frac{M_{j t}+\phi}{z_{i t}}\right],
$$

where $A=[(1-\theta) / \theta]^{\theta}+[(1-\theta) / \theta]^{\theta-1}$. In this case analogs of (A.6)-(A.8) can be easily derived. (A.9) is replaced by the two conditions,

$$
\frac{H_{i t}}{N_{i t}}=\left[\frac{r_{i t}}{w_{i t}}\right]^{\theta}\left[\frac{1-\theta}{\theta}\right]^{\theta}\left[\frac{M_{i t}+\phi}{z_{i t}}\right] \quad \text { and } \quad \frac{K_{i t}^{\theta} H_{i t}^{1-\theta}}{N_{i t}}=\frac{M_{i t}+\phi}{z_{i t}} .
$$

\section{Proof of Proposition 2.1}

The proposition is proved here for the more general case of section 3, which then implies (2.17) subject to the more restrictive assumptions of the economy without capital.

Let $\zeta_{i t}$ denote the Langrange mulitplier on the country $i$ household's period budget constraint, (3.12). The households' first order conditions yield

$$
\beta \frac{U_{c i t}}{q_{i t}}=\zeta_{i t} .
$$

As in Lucas (1982), households' first order conditions with respect to the purchase of the contingent claims profiles $B_{i}\left(S_{t+1}\right)$ imply

$$
\psi\left(S_{t+1}, S_{t}\right)=\left[\frac{\zeta_{i t+1}\left(S_{t+1}\right)}{\zeta_{i t}\left(S_{t}\right)}\right] q_{1 t+1} f\left(S_{t+1}, S_{t}\right) \quad \forall S_{t+1}, S_{t} \quad i=1,2 .
$$

Since (A.15) holds in all states, we have

$$
\frac{\zeta_{1 t+1}}{\zeta_{1 t}}=\frac{\zeta_{2 t+1}}{\zeta_{2 t}} \quad \forall t, t+1
$$


or, using (A.14)

$$
\frac{U_{c 1 t+1}}{q_{1 t+1}} / \frac{U_{c 1 t}}{q_{1 t}}=\frac{U_{c 2 t+1}}{q_{2 t+1}} / \frac{U_{c 2 t}}{q_{2 t}}
$$

Thus, from (A.17), the intial condition,

$$
\frac{U_{c 10}}{q_{10}}=\frac{U_{c 20}}{q_{20}}
$$

implies (3.14). This establishes the proposition.

\section{The Equilibrium Dynamic System}

For computation, a system of fourteen equations is linearized in a neighborhood of the deterministic steady-state. These equations are the "perfect pooling" condition, (3.14); the market clearing conditions for consumption goods, (3.6); the conditional demands for producer goods, (A.11); the laws of motion for the two countries' capital stocks, (3.4), price equals unit cost for consumption goods (the analog of (A.6) with $\alpha \neq 1$ ), and the following for $i=1,2, \ell \neq i$ :

$$
\beta E_{t}\left[U_{c i t+1}\left[r_{i t+1}+\frac{1}{\xi}\left[\frac{X_{i t+1}}{K_{i t+1}}\right]^{1-\xi}\left((1-\delta)+\xi\left(X_{i t} / K_{i t}\right)^{\xi-1}\right)-\left(\frac{X_{i t+1}}{K_{i t+1}}\right)\right]\right]
$$

$$
q_{1 t}=\frac{U_{c_{1 t}}}{U_{c_{10}}}
$$

In this system (A.19) is market clearing for individual producer goods. (A.20) is the household Euler equation for capital, and (A.21) is a normalization condition that establishes the time 0 country 1 consumption good as numeraire. 


\section{References}

Aravanitis, A.V., and A. Mikkola. "Asset Market Structure and International Trade Dynamics", American Economic Review 86(2) (May 1996) 67-70.

Backus, D.K, P.J. Kehoe, and F.E. Kydland. "International Real Business Cycles", Journal of Political Economy 101(4) (August 1992) 745-775.

Backus, D.K, P.J. Kehoe, and F.E. Kydland. "Dynamics of the Trade Balance and the Terms of Trade: The J-Curve?" American Economic Review 84(1) (March 1994) 84-103.

Backus, D.K, P.J. Kehoe, and F.E. Kydland. "International Business Cycles: Theory and Evidence". in T.F. Cooley ed. Frontiers of Business Cycle Research Princeton University Press, Princeton NJ (1995) 331-356.

Baxter, M., and M. J. Crucini. "Explaining Saving-Investment Correlations" American Economic Review 83 (3) (June 1993) 416-36.

Baxter, M. and R.G. King. "Productive Externalities and Business Cycles". Discussion paper No. 53 (Institute for Empirical Macroeconomics, Federal Reserve Bank of Minneapolis) 1991.

Basu, S. and J.G. Fernald. "Returns to Scale in U.S. Production: Estimates and Implications". Journal of Political Economy 105(2) (April 1997) 249-83.

Benassy, J.-P.. "Monopolistic Competition, Increasing Returns to Specialization, and Output Persistence". Economics Letters 52(2) (August 1996) 187-91.

Blanchard, O.J. and C.M. Kahn. "The Solution of Linear Difference Models under Rational Expectations". Econometrica 48(5) (July 1980) 1305-11.

Caballero, R.J. and R.K. Lyons. "External Effects in U.S. Procyclical Productivity," Journal of Monetary Economics 29(2) (April 1992) 209-225.

Caballero, R.J. and R.K. Lyons. "Internal vs. External Economies in European Manufacturing" European Economic Review 34(4) (June 1990) 805-830.

Chirinko, R. and S. Fazzari. "Economic Fluctuations, Market Power, and Returns to Scale: Evidence from Firm-Level Data". Journal of Applied Econometrics 9(1) (January-March 1994) 47-69.

Cole, H.L. and L.E. Ohanian. "Aggregate Returns to Scale: Why Measurement is Imprecise". Quarterly Review, Federal Reserve Bank of Minneapolis 23(3) (Summer 1999) 19-28. 
Devereux, M.B., A.C. Head, and B.J. Lapham. "Aggregate Fluctuations with Returns to Specialization and Scale". Journal of Economic Dynamics and Control 20(4) (April 1996) 627-656.

Ethier, W. "National and International Returns to Scale in the Modern Theory of International Trade", American Economic Review 72(3) (June 1982) 389-405.

Frankel, J.A., and A.K. Rose. "The Endogeneity of the Optimum Currency Area Criteria". Economic Journal 108(449) (July 1998) 1009-1025.

Gregory, A.W., A.C. Head, and J. Raynauld. "Measuring World Business Cycles". International Economic Review 38(3) (August 1997) 677-701.

Grubel, H.G, and P.J Lloyd. Intra-industry Trade: The Theory and Measurement of International Trade in Differentiated Products. MacMillan, London 1975.

Hodrick, R.J. and E.C. Prescott. "Post-war U.S. Business Cycles: An Empirical Investigation", Journal of Money, Credit and Banking 29(1) (February 1997) 1-16.

Hornstein, A. "Monopolistic Competition, Increasing Returns to Scale, and the Importance of Productivity Shocks", Journal of Monetary Economics 31(3) (June 1993) 299-316.

Jones, C.I.. "R\&D Based Models of Economic Growth". Journal of Political Economy 103(4) (August 1995) 759-84.

Lucas, R.E. Jr. "Interest Rates and Currency Prices in a Two Country World". Journal of Monetary Economics 10(3) (November 1982) 335-359.

Markusen, J.R.. "Trade in Producer Services and other Specialized Intermediate Inputs". American Economic Review 79(1) (March 1989) 85-95.

Morrison, C.J. "Market Power, Economic Profitability, and Productivity Growth Measurement". NBER Working Paper No. 3355 (1990).

OECD. Globalisation of Industry: Overview and Sector Reports. Organisation for Economic Cooperation and Development, Paris 1996.

Romer, P.M.. "Growth Based on Increasing Returns to Specialization", American Economic Review 77(2) (May 1987) 56-62.

Stockman, A.C. and L.L. Tesar. "Tastes and Technology in a Two Country Model of the Business Cycle: Explaining International Comovements" American Economic Review 85(1) (March 1995) 168-185. 
Zimmermann, C. "Technology Innovations and the Volatility of Output: An International Perspective". working paper No. 34 (December 1994) Research Center on Employment and Economic Fluctuations, Universite du Quebec a Montreal. 
Table 2: Sample

oments

.S. Data and Artificial Economies

\begin{tabular}{|c|c|c|c|c|c|c|c|c|c|c|c|c|}
\hline \multirow[b]{2}{*}{ Economy } & \multicolumn{6}{|c|}{ Standard Deviation } & \multicolumn{5}{|c|}{ Correlation Across Countries } & \multirow{2}{*}{$\begin{array}{c}\text { Corr. with } \\
\text { Domestic } Y \\
N X / Y\end{array}$} \\
\hline & $Y$ & $C$ & $X$ & $H$ & $S R$ & TOT & $Y$ & $C$ & $X$ & $H$ & $S R$ & \\
\hline $\begin{array}{l}\text {.S. Data } \\
\text { 1970.1-1990.2 }\end{array}$ & 1.92 & 1.44 & 6.28 & 1.17 & 1.31 & 3.68 & .66 & .51 & .53 & .33 & .56 & -.37 \\
\hline $\begin{array}{l}\text { Baseline Calibration } \\
\lambda+1 / \rho=1.9\end{array}$ & $\begin{array}{l}1.85 \\
(.002)\end{array}$ & $\begin{array}{c}.677 \\
(.001)\end{array}$ & $\begin{array}{c}6.23 \\
(.008)\end{array}$ & $\begin{array}{c}.854 \\
(.001)\end{array}$ & $\begin{array}{l}1.31 \\
(.002)\end{array}$ & $\begin{array}{l}.161 \\
(.000)\end{array}$ & $\begin{array}{l}.485 \\
(.131)\end{array}$ & $\begin{array}{l}.810 \\
(.064)\end{array}$ & $\begin{array}{c}.343 \\
(.147)\end{array}$ & $\begin{array}{l}.293 \\
(.154)\end{array}$ & $\begin{array}{c}.570 \\
(.114)\end{array}$ & $\begin{array}{l}-.187 \\
(.167)\end{array}$ \\
\hline $\begin{array}{l}\text { Constant Int'l Returns } \\
\lambda+1 / \rho=1\end{array}$ & $\begin{array}{c}1.07 \\
(.001)\end{array}$ & $\begin{array}{c}.267 \\
(.000)\end{array}$ & $\begin{array}{c}3.53 \\
(.004)\end{array}$ & $\begin{array}{l}.580 \\
(.001)\end{array}$ & $\begin{array}{c}.698 \\
(.001)\end{array}$ & $\begin{array}{l}.122 \\
(.000)\end{array}$ & $\begin{array}{l}-.311 \\
(.151)\end{array}$ & $\begin{array}{l}.388 \\
(.150)\end{array}$ & $\begin{array}{l}-.349 \\
(.144)\end{array}$ & $\begin{array}{l}-.493 \\
(.127)\end{array}$ & $\begin{array}{l}-.195 \\
(.157)\end{array}$ & $\begin{array}{l}.121 \\
(.134)\end{array}$ \\
\hline $\begin{array}{l}\text { igh Elasticity } \\
\rho=.95\end{array}$ & $\begin{array}{l}1.63 \\
(.002)\end{array}$ & $\begin{array}{l}.586 \\
(.001)\end{array}$ & $\begin{array}{l}5.39 \\
(.007)\end{array}$ & $\begin{array}{l}.765 \\
(.001)\end{array}$ & $\begin{array}{l}1.14 \\
(.001)\end{array}$ & $\begin{array}{l}.038 \\
(.000)\end{array}$ & $\begin{array}{l}.578 \\
(.112)\end{array}$ & $\begin{array}{l}.911 \\
(.031)\end{array}$ & $\begin{array}{l}.478 \\
(.126)\end{array}$ & $\begin{array}{l}.358 \\
(.144)\end{array}$ & $\begin{array}{l}.671 \\
.091)\end{array}$ & $\begin{array}{l}-.034 \\
(.173)\end{array}$ \\
\hline $\begin{array}{l}\text { Low Ad ustment Costs } \\
\xi=.99\end{array}$ & $\begin{array}{c}2.28 \\
(.003)\end{array}$ & $\begin{array}{l}.653 \\
(.001)\end{array}$ & $\begin{array}{c}9.69 \\
(.013)\end{array}$ & $\begin{array}{l}1.20 \\
(.001)\end{array}$ & $\begin{array}{l}1.50 \\
(.002)\end{array}$ & $\begin{array}{l}.501 \\
(.001)\end{array}$ & $\begin{array}{l}.498 \\
(.125)\end{array}$ & $\begin{array}{l}.807 \\
(.072)\end{array}$ & $\begin{array}{l}.003 \\
(.156)\end{array}$ & $\begin{array}{l}.389 \\
(.137)\end{array}$ & $\begin{array}{l}.588 \\
(.105)\end{array}$ & $\begin{array}{l}-.356 \\
(.138)\end{array}$ \\
\hline $\begin{array}{l}\text { Correlated Shocks } \\
\lambda+1 / \rho=1 \\
\quad \operatorname{rr}\left(\epsilon_{1}, \epsilon_{2}\right)=.7\end{array}$ & $\begin{array}{l}.870 \\
(.001)\end{array}$ & $\begin{array}{l}.278 \\
(.000)\end{array}$ & $\begin{array}{l}2.89 \\
(.003)\end{array}$ & $\begin{array}{l}.430 \\
(.001)\end{array}$ & $\begin{array}{l}.599 \\
(.001)\end{array}$ & $\begin{array}{l}.062 \\
.000)\end{array}$ & $\begin{array}{l}.486 \\
(.123)\end{array}$ & $\begin{array}{l}.853 \\
(.048)\end{array}$ & $\begin{array}{l}.451 \\
(.126)\end{array}$ & $\begin{array}{l}.302 \\
(.144)\end{array}$ & $\begin{array}{l}.569 \\
(.110)\end{array}$ & $\begin{array}{l}.085 \\
(.180)\end{array}$ \\
\hline
\end{tabular}

otes: Variable definitions are: $Y$, output; $C$, consumption; $X$, investment; $H$, employment; $S R$, Solow residual (defined in text); TOT terms of trade (defined in text); $N X$, net exports. Moments are sample means over 1000 trials 126 periods in length. Standard deviations of the sample moments are in parentheses. Artificial data are in logarithms and are detrended using the filter of Hodrick and Prescott (1997) with smoothing parameter 1600. U.S. Data moments are taken from Backus, Kehoe, and Kydland (1995) pp333-36. Cross-country correlations in this row are for the U.S. and a constructed European aggregate. For baseline calibration parameters, see Table 1. 


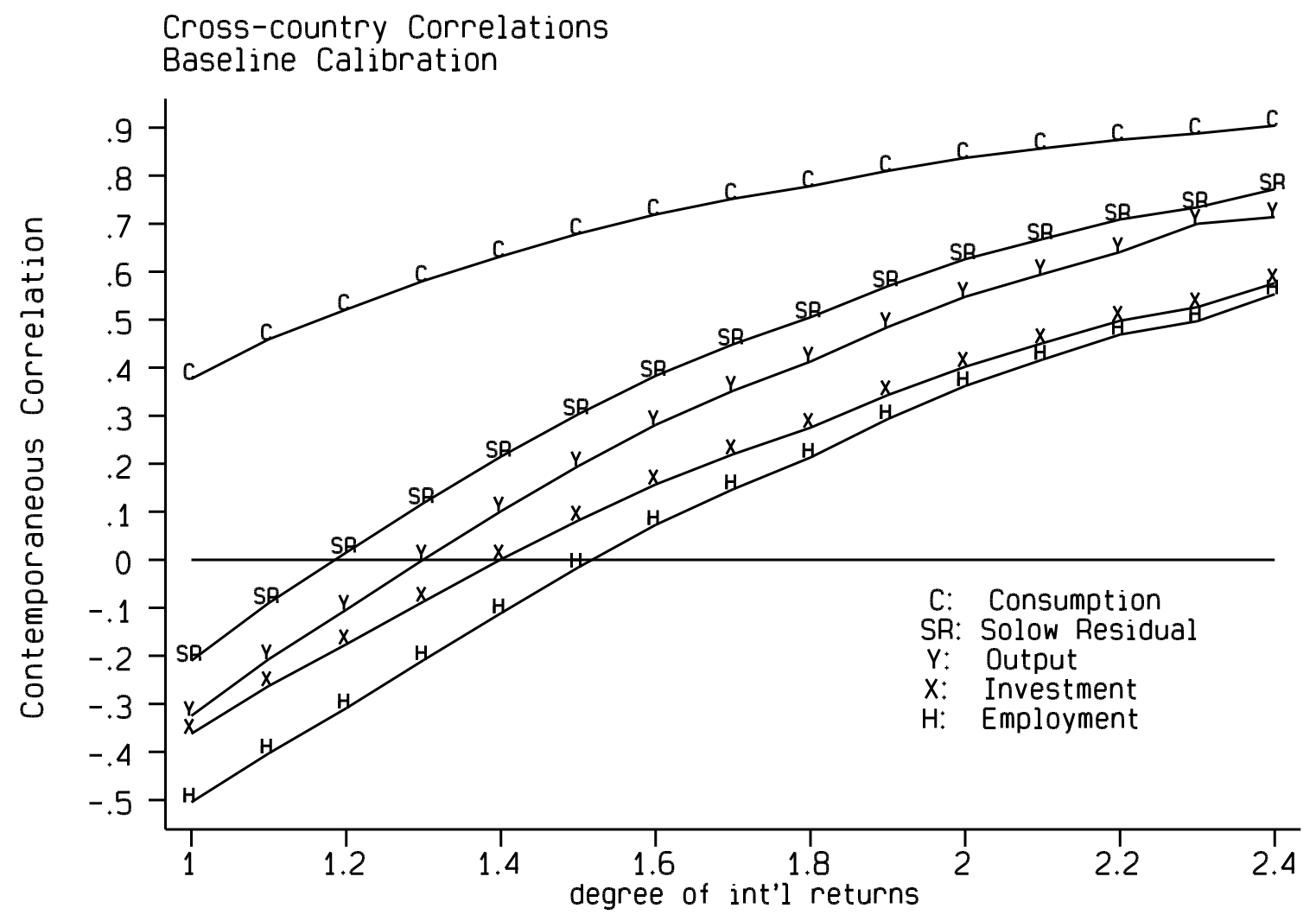

Figure 1: Co-movements and International Returns to Scale 

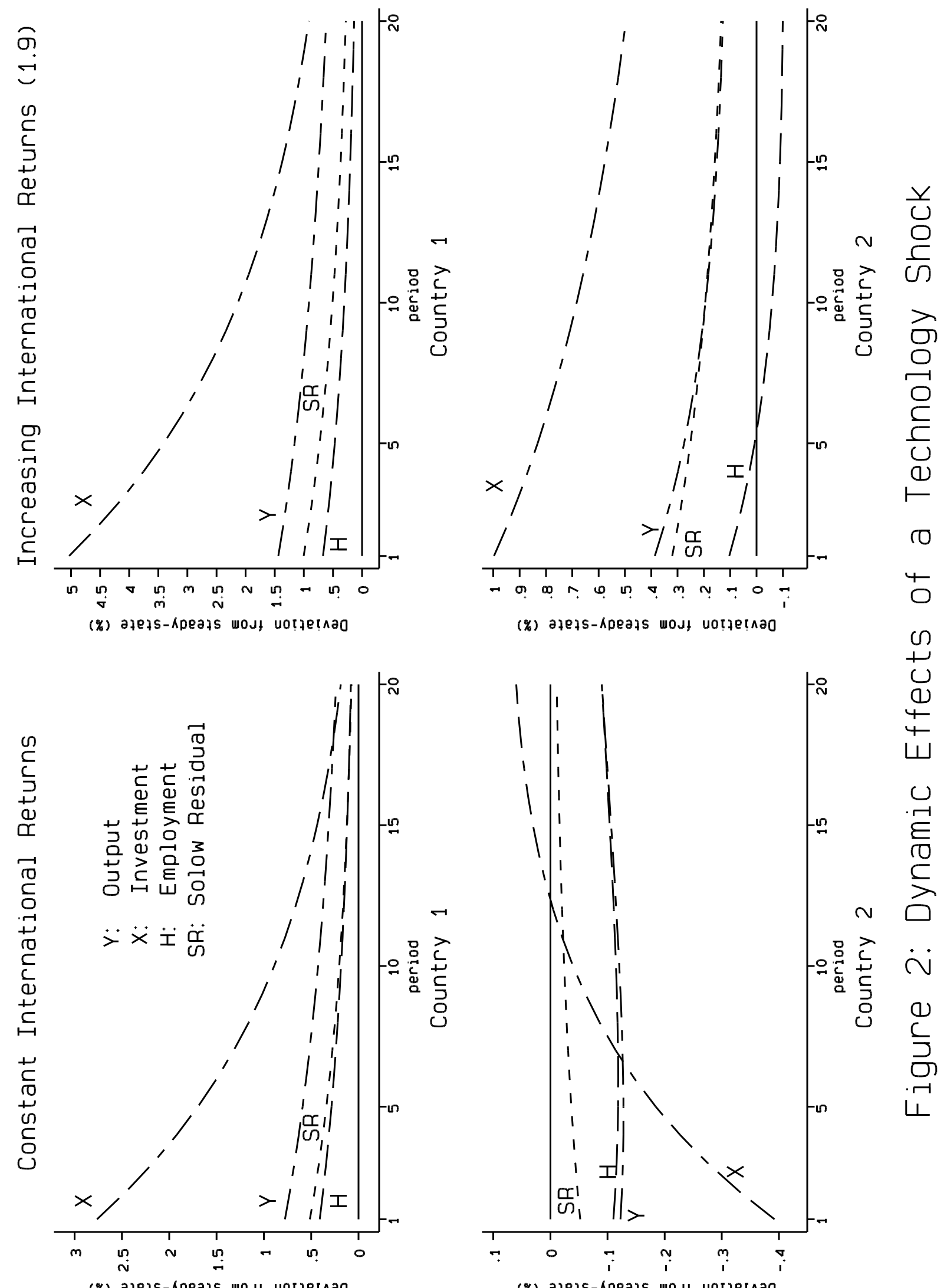

(\%) ajejs-kpeajs wouf uotfetna0

(\%) ajejs-npeazs wout uotgetnao 